\title{
Traducerile în română ale legislației austriece pentru provincia Bucovina (1775-1918)
}

\author{
Iulia Elena Zup* \\ Facultatea de Drept, Universitatea ,Alexandru Ioan Cuza”, Bd. Carol I 11, 700506 Iaşi, România
}

\section{Despre articol}

Istoric:

Primit 6 februarie 2019

Acceptat 26 februarie 2019

Publicat 7 mai 2019

Cuvinte-cheie:

traducere

stilistică

împrumut lexical

\begin{abstract}
Rezumat
Prezenta lucrare tratează contextul în care a fost tradusă în română legislația Imperiului Habsburgic pentru provincia Bucovina şi identifică trei perioade de traducere corespunzătoare transformărilor administrative majore și evoluției stilului juridic românesc. Rolul traducerilor este analizat în cadrul procesului de transfer cultural între centru şi periferie, accentul fiind pus pe strategiile lingvistice utilizate de traducători, care au compensat astfel neajunsurile unui limbaj și gîndiri juridice la un stadiu de evoluție inferior față de cel german. Este evaluat impactul traducerilor asupra evoluției culturale și lingvistice a României.
\end{abstract}

\section{Introducere}

O dată cu anexarea sa de către Imperiul Habsburgic în anul 1775, spațiul bucovinean nu mai este unul omogen, ci unul despărțit și împărțit de moldoveni și cunoscători ai limbii germane, de boieri și țărani autohtoni și funcționari și ofițeri ai administrației militare, de imigranți germani și evrei. Demersurile împărătesei Maria Teresia de centralizare a administrației din a doua jumătate a sec. al XVIII-lea presupun și utilizarea exclusivă a limbii germane în toate instituțiile statului. Aceste încercări de centralizare și simplificare a administrației sînt continuate de fiul său, împăratul Iosif al II-lea, în acest scop acesta introducînd în anul 1784 germana ca limbă oficială, limbă a administrației și justiției în întreg imperiul, înlocuind astfel latina.

Din asimetria funcțională a folosirii și prestigiului limbilor-germană, română, rutenă—în Bucovina decurge o ierarhizare a acestora, care oglindește raporturile de putere. În contextul acestor constelații lingvistice există diferențe în atitudinea faţă de diferitele domenii de utilizare, conflictele apărînd mai cu seamă în domeniul învăţămîntului sau administrației, mai puţin în domeniul medical spre exemplu. Astfel, fenomenul traducerii a servit nu doar ca mijloc de comunicare între culturi, ci a reprezentat un mediu al transferului cultural, aducînd un aport considerabil la construcția culturilor spațiului habsburgic. Prin traducere se ajunge la reinterpretări continui și transformări, care dinamizează hotărîtor cultura receptoare și duce în același timp la rupturi, toate acestea întărind sau slăbind raporturile de putere asimetrice. În analiza traducerilor hotărîtor este în ce măsură au avut loc procese de transfer discursiv între cele două culturi. Un alt element important este raporturile ierarhice între actorii implicați. Raporturile de putere condiționează procesele comunicative la toate nivelele; pornesc de la încordări între grupurile sociale și pătrund astfel în întîmplarea comunicării în conflictele dintre naţionalităţi, care influențează hotărîtor mecanismele de realizare ale comunicării. Conflictele între națiuni rezultă într-o creștere a conștiinței naționale, care solicită crearea de produse culturale originale. Pe fundalul mișcărilor sociale din anul 1848, constituțiile imperiale din 25 aprilie 1848, respectiv 4 martie 1849 conţineau prevederi liberale privitoare la limbile imperiului, garantînd tuturor cetățenilor prin art. 4 inviolabilitatea națiunii și limbilor naționale.

Bucovina reprezintă un spațiu al suprapunerii culturilor, unde are loc negocierea între culturi, unde se întîlnesc forțe asimetrice, disonanța și ceea ce nu este sau nu poate fi rostit. Caracterul de construct

*Adresă de corespondență: iuliazup@gmail.com. 
Iulia Elena Zup

al traducerii pornește tocmai de la acest concept al culturii, care ia în considerare procesele cu mai multe fețe rezultînd din contactul cultural al constituirii de sens și al noii contextualizări. Caracterul dialogic, polifon, de interacțiune al traducerii participă la construcția culturii receptoare, permițind modificarea, înnoirea și transformarea. Astfel, cultura bucovineană poate fi interpretată și ca rezultat al proceselor de traducere.

Pornind de la categoriile introduse de Kremnitz (1994, p. 24, 38) referitoare la bilingvism, și anume bilingvismul simetric, desemnînd competențe similare în cele două limbi, și bilingvismul asimetric, care desemnează competențe mai complexe într-o limbă în comparație cu cea de-a doua, putem spune că, la începuturile dominației habsburgice, spaţiul bucovinean este caracterizat printr-un bilingvism asimetric, progresînd ulterior — prin introducerea germanei în administraţie, înființarea de școli în limba germană și accesul la studii în cadrul Universității din Viena-spre un bilingvism simetric. În aceeaşi măsură sînt relevante conceptele de bilingvism instrumental sau funcțional și cel integrativ, primul referindu-se la extinderea competențelor de exprimare în cealaltă limbă, al doilea la integrarea, prin învățarea sau aprofundarea celei de-a doua limbi, într-o societate (nouă) sau categorie socială. Accesul la structurile puterii, la o evoluție ierarhică este condiționat de însușirea celei de-a doua limbi, a centrului. Bilingvismul este un fenomen care depășește granițele sociale, prin contactul lingvistic fiind realizate interferențe, împrumuturi și modificări lingvistice.

\section{Etapele de traducere}

Activitatea intensă de traducere se datorează mai multor factori: limba oficială era germana, legislația trebuia cunoscută de toți locuitorii imperiului, noile reglementări constituționale din 1849 prevedeau ridicarea limbilor autohntone la rang oficial, și prin urmare obligativitatea publicării legilor în toate limbile imperiului. Traducerile pentru Bucovina pot fi delimitate şi analizate pe trei perioade, care corespund perioadelor administrative, precum și perioadelor evoluției stilului juridic românesc (Zup, 2015b):

2.1. În prima perioadă, între 1775 și 1848 , Bucovina a fost sub administrație militară imediat după anexare (1775-1786), apoi integrată Regatului Galiției și Lodomeriei (1786-1849). Ca urmare a introducerii limbii germane ca limbă oficială, în prima etapă sînt traduse acele acte privitoare la incorporarea Bucovinei, apoi cele mai importante legi au fost transpuse în română sub îndrumarea lui Vasile Balș de traducătorii Ion Budai-Deleanu și Georg Oechsner. Alte documente administrative şi ordine publicate sub formă de foi volante au fost traduse de funcționari publici și copiști. Traducerile din această perioadă se înscriu întro epocă a transformărilor la nivel lingvistic, constatarea posibilităților de expresie mai reduse ale românei în comparație cu idiomurile occidentale (prin constatarea lipsei de expresii și termeni echivalenți celor din germană, în cazul de față) generînd o activitate intensă de cultivare a limbii (Minuț \& Lihaciu, 2014, p. 92). S-a încercat depășirea acestor neajunsuri prin alcătuirea de dicționare și gramatici sau alte lucrări de lingvistică. Conștientizarea necesității sincronizării demersului de redactare a textului românesc cu reperele culturale occidentale marchează intrarea în perioada modernă a culturii noastre.

2.2. În a doua perioadă, între 1849 , cînd Bucovina își cîștigă autonomia în cadrul Imperiului Austriac și devine ducat, și 1918, cînd este integrată Regatului României, se realizează foarte multe traduceri în primă linie ale actelor constituționale de la începutul perioadei, ale codurilor civil, penal și procedural. În această perioadă apare și varianta în română a Reichsgesetzblatt - Foaia legilor imperiale și publicația Dietei Bucovinei conținînd legislația și ordonanțele acesteia, Landesgesetzblatt - Foaia legilor provinciale, dar și unele dicționare și lucrări de referință pentru funcționarii din administrație și traducători. În această perioadă are loc o nouă dezvoltare a limbajului juridic, odată cu unificarea legislației în Țările Române prin introducerea codurilor penal și civil în 1864, denumite și „,codurile Cuza”.

2.3. În perioada între 1918 și 1938, în regiunea Bucovina rămîn în vigoare majoritatea prevedelor din legislația austriacă, pentru care sînt în continuare realizate traduceri pentru un public mult mai larg, chiar 
și în alte regiuni ale Regatului României. În plus, legislația românească este tradusă în limba germană pentru cetățenii bucovineni vorbitori de germană. Din punct de vedere lingvistic, tendința este de unificare a limbajului juridic. Activitatea de traducere din această perioadă poate fi analizată dintr-o perspectivă postcolonială cu privire la urmările tîrzii ale procesului de colonizare.

În ceea ce privește terminologia utilizată în textele românești, pentru cuvintele germane de specialitate traducătorul face uz de:

- termeni juridici de strictă specialitate care pot fi considerați împrumuturi savante (monosemantism);

- cuvinte din vocabularul general utilizate ca termeni juridici (polisemia) - aici se recurge la două mijloace: inserarea cuvintelor în sintagme specializate cu caracter juridic și redefinirea în cadrul textului.

Cuvintele noi introduse după modelul textului-sursă german sînt de două tipuri:

a) neologisme, ale căror semnificații sînt explicate de unii traducători printr-o strategie de traducere, și anume introducerea, intercalarea de cuvinte sau fraze ce nu aparțin originalului, pentru a oferi o explicație. Această strategie are menirea să corecteze discrepanțele lingvistice și culturale, prin extinderea textului-sursă fiind vizate elemente de limbă, cultură, civilizaţie, considerate ca fiind necunoscute cititorului (Minuț \& Lihaciu, 2014, p. 98). Explicația apare sub formă de:

- glosă, adică menționarea unei alte variante de traducere, a unui sinonim în paranteză;

- interpolare, adică menționarea unei alte variante de traducere introdusă prin conjuncția sau.

Spre deosebire de glosă, interpolarea „nu segmentează lectura cititorului care, pe de altă parte, nu poate însă distinge între vocea textului și vocea traducătorului” (Minuț \& Lihaciu, 2014, p. 98).

b) calcuri-cuvinte formate din material autohton care împrumută forma internă și/sau sensul unor cuvinte străine din germană. Acestea sînt de trei tipuri:

- calcul de structură, prin care se formează un nou cuvînt prin contopirea a două cuvinte sau prin derivare cu prefixe sau sufixe;

- calcul semantic, prin care unui cuvînt îi este atribuit un nou sens, după modelul german;

- calcul sintagmatic, prin care se calchiază o unitate frazeologică germană sau un cuvînt german compus (Cujbă, 1999).

\section{Analiza traducerilor codurilor penale}

În continuare, ne vom limita la o scurtă analiză a traducerilor codului penal în primele două perioade ${ }^{1}$.

Primul cod penal austriac în vigoare în Bucovina este codul penal terezian, Constitutio Criminalis Theresiana (1768), în limba română fiind tradusă doar partea a doua în formă prescurtată, de rezumat, sub titlul Publicație cuprinzînd abaterile și pedepsele ce se vor aplica celor vinovați (1780). În ceea ce privește lexicul, se poate observa folosirea limbajului comun, nespecializat la acea dată. Întrucît în limba română nu existau termenii care să desemneze o anumită calitate infracțională, traducătorul recurge la unele strategii, şi anume:

a) explicarea substantivului german, de regulă abstract, printr-o propoziție subiectivă:

- cel ce va defäima pe Dumnezeu - Gotteslästerung (art. 1);

- cel ce va schimba legea creștinească - Abfall von christlichen Glauben (art. 2);

- cel ce va giura strîmb sau va strîca giurämîntul lui - Von falschen Schwüren, und Meineid (art. 4);

- cel ce va curvi cu sîngele său - Von der Blutschand (art. 15);

- cel ce va sili pre oare cineva cu sila spre curvie - Von der Nothzucht (art. 16);

\footnotetext{
${ }^{1}$ Pentru o analiză a traducerilor legislației din germană în română, din toate materiile juridice, vezi Zup (2015b).
} 
- celce va avea douămueri sau mai multe, sau muiarea doibărbați-Von zweifacher Ehe/Doppelte Ehe (art. 18).

b) folosirea de verbe substantivizate sau adjective pentru termenii abstracți din germană:

- un răzvrătitoriu și zurbagiu - Von Aufruben, und Tumulten (art. 6);

- însurații sau măritații de vor curvi cu altul - Von dem Ehebruch (art. 17);

Rareori se găsește în română termenul abstract, echivalent celui din germană:

- uciderea, rănirea și alte fapte de moarte - Von dem Todschlag, so im Getümmel, und Schlägeren unter vielen Leuten begangen wird (art. 23);

- curvia de obște - von gemeiner Hureren (art. 21).

În anul 1787 intră în vigoare codul penal iosefin ${ }^{2}$, Allgemeines Gesetz über Verbrechen und derselben Bestrafung, textul tradus în română de Ioan Budai-Deleanu fiind publicat în 1788 sub titlul Pravilă de obște asupra faptelor rele și a pedepsirii lor. Chiar din titlu se remarcă arhaismul textului: pravilă (Gesetz) lege pentru popor; de obște - cetățenesc, oficial, în acest context folosit pentru general, allgemein. Întrucît în limba română nu exista un termen special pentru Verbrechen (infracțiune), traducătorul introduce sintagma fapte rele, iar pentru Verbrecher (infractor) - făcătoriu de rău criminălesc. Practic, în acest context, traducătorul apelează la calcuri lingvistice pentru a reda în limba română realități juridice pentru care nu exista încă un vocabular. De asemenea, în patentul de publicare se observă frecvența gloselor:

- să să nimerească (chibzuiască) dreapta potrăvire (proporție), p. 2 - das billige Ebenmaßzu treffen;

- intipărirea (lucrarea), p. 2 - Einbruck (întipărirea fiind un calc format după termenul german).

Faptul că în această lucrare apar moldovenisme, cum ar fi $\breve{g}$ în agiunge sau forma tatul îl determină pe Gheție (1975, p. 481) să îi aloce un loc aparte printre textele tipărite la Viena în această perioadă și să presupună că un bucovinean ar fi colaborat într-o formă sau alta la traducerea, revizuirea sau tipărirea cărții (probabil Vasile Balș). În ceea ce privește deosebirile dialectale față de normele literare, lingvistul constată următoarele deosebiri fonetice:

- iá păstrat peste tot, de exemplu în încuiată (p. 75);

- îîn mînile, pine (p. 25, 109);

- labialele sînt aproape fără excepție moi: să se lovească (p. 106), însă să să scobască (p. 15);

- $s, z, t$, duri apar mult mai frecvent decît în celelalte texte: încredințază (p. 59), năsîlnică (p. 48), să să preiuțască (p. 37), treizăci (p. 106);

- în general, ş,j (+e) sînt moi, însă ş, $j$ duri apar cu oarecare insistență: aşezate (p. 78), grije (p.71), inșelăciunii (p. 29), înşălătoare (p. 48);

- în privința fonetismelor de tipul slujęște (slujeşte) - slujaşte, șępte (șepte) - șapte, se constată un amestec de rostiri dure și moi, cu predominarea celor din urmă: păssesște (p. 97), slujesște (p. 38), a șéptelea (p. 94), șaselea (p. 77);

- forma să hotărèste (p. 129, 135);

- destul de frecvente cazuri de folosire a articolului posesiv a invariabil: a(l) patriei (p. 27), a(le) statului (p. 37);

- forme verbale cu dentala refăcută: să cadă (p. 112), să scoată (p. 115) și forme iotacizate: să rămîie (p. 57), să spuie (p. 28, 157), să scoață (p. 29);

- destul de frecvente forme în -ě̀ie (-aie) la conjugarea la prezent persoana 3 singular și plural a verbelor a da și a lua: să (să, se) déie (p. 53), să iaie (p. 104);

- $m$ păstrat în au rumptu (p. 91);

- rostirea dură a lui $n$ în năsîlnică (p. 48);

- $n>r$ în amăruntul (p. 109);

şi morfologice:

- tată are forma articulată tatul (p. 59) (Gheție, 1975, p. 474-479).

\footnotetext{
${ }^{2}$ Pentru o analiză a codului penal iosefin din perspectiva istoriei dreptului și istoriei culturii, vezi Zup (2015a).
} 
Greutățile întîmpinate de traducătorii români au fost subliniate de Balș, care, semnalînd că unele ordonanțe au fost traduse într-o asemenea manieră încît nu pot fi înțelese de locuitorii Bucovinei, arată Înaltei Curți de Justiție din Viena sărăcia și provocările limbajului juridic românesc: „În jurisprudență există termeni pentru care în limba țării nu se găsesc cuvinte, ci doar expresii echivalente, ceea ce cere o definire exactă a cuvintelor prin acele expresii pe care nu poate să le redea decît un om perfect stăpîn pe limbă”3. Această definire presupunea de cele mai multe ori calchierea termenului german, ceea ce însemna implementarea de noi realități de ordin juridic în gîndirea și stilul juridic românesc.

Greutățile erau dublate de inexistența la acea dată a unui vocabular terminologic juridic și administrativ pentru limba română. Pentru a compensa aceste neajunsuri, Vasile Balş, Ion Budai-Deleanu și Georg Oechsner publică în 1787 un dicționar juridic german-român, titlul acestuia apărînd în catalogul bibliotecii lui Budai-Deleanu: Deutsch-Wallachisches Wörterbuch über Verbrechen [Dicționar german-valah despre infracțiuni]. O însemnare din protocoalele Cancelariei Aulice a Galiției din 1788 rezumă decretul către Guvernul Galiției prin care se stabilea prețul de 25 de creițari pentru vînzarea unui exemplar din o carte juridică „über Verbrechen und Strafen in deutsch- und moldauischer Sprache” [despre infracțiuni și pedespe în limbile germană-moldovenească], expediate la Liov. Conform prețului, aceasta conținea doar cîteva file. Din păcate nu s-a identificat nici un exemplar al acestui dicționar, însă putem evalua importanța acestuia în evoluția limbajului juridic românesc prin oferirea unor echivalente ale termenilor juridici germani şi latini, într-o epocă în care, la nivel european, limbajul juridic era maturat, elaborarea de dicționare find o preocupare comună. Astfel, și traducătorii bucovineni s-au încadrat în tendința ce se putea observa la nivel european, de a alcătui materiale ajutătoare atît pentru munca de traducător, cît și pentru înțelegerea mai profundă a textelor juridice, a căror hermeneutică începe a deveni din ce în ce mai complexă. Astfel de dicționare apăruseră cu cîțiva ani în urmă în Germania (De verborum que ad Jus civile pertinent significatione, Haale, 1743, sau Eberhard J.H., Kritisches Wörterbuch über juristische Sachen, 1769-1772). Putem conchide că Deutsch-Wallachisches Wörterbuch über Verbrechen a pavat drumul viitoarelor dicționare și glosare juridice românești, precum cel publicat de Flechtenmacher \& Cuzanos (1815) la Iași, și, împreună cu lexiconul lui Budai-Deleanu, al dicționarelor pentru limbile germană şi română, tipărite la începutul sec. al XIX-lea: Kleines walachisch-deutsch und deutsch-walachisches Wörterbuch (1821) de Andreas Clemens, Wörterbuchlein deutsch und walachisches $=$ Vocabularium nemțesc și românesc (1822, Sibiu) de Ioan Piuariu Molnar, Lesicon romanescu-latinesc-unguresc-nemțesc (1825, Budapesta).

În 1804 intră în vigoare un nou cod penal, Gesetzbuch über Verbrechen und schwere Polizey-Uebertretungen, traducerea în română, realizată de Toma Moldovan și revizuită de Ioan Budai-Deleanu, fiind publicată în $1807 \mathrm{cu}$ titlul Carte de pravilă ce cuprinde legele asupra faptelor răle și a călcălilor grele de poliție. Particularitățile textului în română constau în folosirea limbajului uzual, nespecializat, inconsecvența în utilizarea termenilor, interpolări și calchieri (rodul pîntecelui - Leibesfrucht, art. 128; făcătoriu de criminal - Verbrecher, art. 132).

În anul 1852, în urma schimbărilor rezultate după revoluția paşoptistă, intră în vigoare o nouă variantă modificată și completată a codului penal: Das Strafgesetz über Verbrechen, Vergehen und Uebertretungen, die Strafgerichts-Competenz-Verordnungen und die Press-Ordnung vom 27. Mai 1852 für das Kaiserthum Oesterreich, tradusă în română de Eudoxiu Hurmuzachi și publicată în 1853 sub titlul Codicele penale despre crimini, delipte și abateri, ordinăciunile despre competința județelor penali, și regulămîntul de tipariu din 27 mai 1852 pentru Imperiul Austriei. Așa cum se poate observa din titlu, această traducere conține noi termeni de specialitate, Hurmuzachi introducînd foarte multe neologisme ce compensau deficitele unui limbaj juridic puțin specializat și aflat pe o treaptă inferioară de dezvoltare faţă de cel german. Prin comparație cu traducerea vechiului cod penal, reiese că Strafgesetzbuch este tradus acum prin codicelepenale în loc de carte de pravilă, iar Verbrechen prin crimini în loc de fapte rele.

Gheție (1975, p. 531, 538-540), deși remarca că pentru perioada 1836-1881, literatura juridică pentru spațiul românesc cuprins în Imperiul Habsburgic este „neînsemnată” —în ciuda apariției și a codului

${ }^{3}$ Haus-, Hof- und Staats-Archiv, Wien, St. R., Nr. 8/1787, anexa XIII, apud Protopopescu (1967), p. 102. 
civil, de procedură penală, a actelor constituționale—, face totuși cîteva observații cu privire la diferențele dialectale cuprinse în codul penal tradus de Hurmuzachi, și anume:

- foarte rare cazuri de trecere a lui $e$ medial aton la $i$ aseminea (p. 10);

- grafii hipercorecte (latinizante), prezentînd $e$ și $i$ după ț: ațițare (p. 103), țeri (p. 6);

- $j$ notează pe $j+o, u$ latin, iar $\breve{g}$ e întrebuințat pentru redarea în scris a lui jur și a cuvintelor înrudite: împregiurări(le) (p. 12);

- $r$ dur alternează cu $r$ moale în cuvinte de tipul argintar, croitor: făptorul (p. 12), tipăritorului (p. 204), vînzătorul (p. 14) - ajutoriu (p 13);

- forme cu dentală refăcută: să prevadă (p. 42), să se pună (p. 7), să se scoată (p. 24);

- topica auxiliarului $a$ la indicativ perfect compus persoana 3 este preluată din originalul german: datu-s-a (p. 10);

- forma să deie (p. 13);

- ă nu a trecut la î în pănă (p. 6);

- ă păstrat în năsip (p. 13);

- e > ă în lăpădătură (p. 187), străin (p. 23);

- e păstrat în prevegheare (p. 15);

- iu păstrat în minciunoasă (p. 77);

- $n>r$ în amerință (p. 99).

Cu toate că Hurmuzachi introduce mulți termeni noi în textul din 1853, aceasta însă nu duce la o claritate mai mare în comparație cu textele din 1788 și 1807, dovadă fiind faptul că doar unii dintre aceștia au reușit să pătrundă în limbajul modern românesc. Este de remarcat că Eudoxiu Hurmuzachi utilizează interpolări pentru explicarea unor termeni din germană, oferind o a doua sau chiar a treia variantă prin folosirea conjuncției sau:

- violența publică sau pe față - Öffentliche Gewaltthätigkeit (art. 76-100);

- rapină sau răpitoriă sau lotriă - Raub (art. 190-196);

- abort sau lepădătură făcută - Abtreibung des Leibesfrucht (art. 144-148).

Interpolarea era mai rar întîlnită la Budai-Deleanu: duell sau combat (1788, art. 89), război între doi sau volnica ucidere (1807) - Zweikampfe.

Traducătorii sînt inconsecvenți în folosirea anumitor termeni juridici, nu doar în traducerea unei noi versiuni a codului, dar chiar în cadrul aceluiași text: öffentlich este tradus spre exemplu în 1788 și 1807 o dată prin vederat (în sensul de vizibil), apoi prin de obște (public).

Din analiza comparativă a traducerilor, se remarcă faptul că, atunci cînd textul german este identic sau foarte asemănător cu cel din codul penal anterior, abrogat, traducătorul român nu recurge la traducerea anterioară; mai mult, nici măcar nu folosește aceiași termeni pentru a desemna același concept, fapt care ar fi putut duce la multe confuzii în interpretarea legilor, dacă germana nu ar fi fost limba oficială. Deși anumite fragmente din codul penal din 1853 sînt identice cu cele din codul anterior, Hurmuzachi nu se folosește de traducerea mai veche. Mai mult, în exemplele de mai jos se pot remarca unele neologisme introduse de acesta, în comparație cu limbajul folosit de Budai-Deleanu:

- a comite (o infracțiune) în loc de a face pentru begehen;

- färă a ave facultate în loc de nefiind volnic pentru unbefugt;

- in cerculăciune în loc de umblătoriu pentru im Umlaufe;

- ginuină în loc de drepți pentru echt;

- carcere în loc de temniță pentru Kerker (acest neologism chiar din germană).

În ceea ce privește explicarea neologismelor, Hurmuzachi se folosește de două strategii:

- glosa: soții criminei (conculpați și complici) (art. 5);

- interpolarea: cugetuls. propusul rău (art. 1). 


\section{Concluzii}

Concluziile noastre sînt în conformitate cu teoria dezvoltată de Coșeriu (1998, p. 9), și anume competențele traducătorului nu țineau doar de prima fază a traducerii, cea semasiologică (faza de înțelegere a ceea ce desemnează textul original), în care cunoștințele de natură juridică au fost foarte esențiale, ci și de cea de-a doua, onomasiologică, în care acesta trebuia să găsească în limba țintă semnificațiile care să redea întocmai desemnările identificate în textul original. Neajunsurile unui limbaj la un stadiu de evoluție inferior față de cel german au fost compensate, măcar parțial, prin diferite metode. Caracteristice traducerilor sînt frazele lungi, cu multe determinări și intercalări, construite sub influența textului german, și o ortografie etimologică. De abia la începutul secolului XX limbajul juridic, așa cum se regăsește în traducerile legislației austriece, ajunge la maturitate.

În prima etapă a traducerilor, lexicul juridic este de factură populară, tradițională, germana oferind sub aspect semantic posibilitatea de a îmbogăți (prin calchiere) vechile cuvinte românești, spre exemplu în traducerea lui Ion Budai-Deleanu fapte rele pentru infracțiune, făcător de rău pentru infractor. În a doua perioadă, ea a participat în mare măsură și la introducerea, fixarea și îmbogățirea semantică a împrumuturilor neologice, care constituie majoritatea elementelor ce alcătuiesc terminologia juridică românească actuală. Sub acest aspect, limba germană a putut coopera mai ales prin lexicul ei neologic, prin termenii filosofici de proveniență greco-latină sau romanică, comparabili acelora care intrau în limba noastră din latină, greacă, franceză și italiană (Jumugă, 1986, p. 41-46). Confruntarea dintre tradiție și inovație are drept rezultat coexistența unor aspecte cu caracter arhaic și popular cu inovații lingvistice. Desigur, numeroși termeni specializați au etimologie multiplă, spre exemplu rom. Avocat - lat. Advocatus, germ. Advokat, it. Avvocato, fr. Avocat, aserțiunea noastră fiind faptul că aceștia ar fi putut intra mai degrabă pe filieră germană, cel puțin în zona Bucovinei, datorită numărului mare de traduceri în română.

Introducerea neologismelor din germană prin intermediul traducerilor legislației austriece a fost susținută și dublată în a doua jumătate a secolului al XIX-lea de dezvoltarea facultăţilor de drept din Iași și București, unde profesorii, dintre care majoritatea studiaseră în spațiul german, țineau cursuri scrise în baza lecturilor străine, printre care și în germană, după cum se poate observa atît din bibliografie, cît și din terminologia utilizată (Cujbă, 1999, p. 76).

Prin intermediul traducerilor juridice pentru regiunea Bucovina, dar şi prin accesul direct la literatura juridică austriacă (de exemplu, prin profesorul de drept, traducătorul și juristul ieșean Christian Flechtenmacher), reformele iosefine și post-iosefine sînt cunoscute și în principatele Moldova și Țara Românească. Astfel, juriștii români pot să-şi însușească principiile iosefine, și mai apoi cele neoliberale, pentru a încerca ulterior să le adapteze la realitățile locale. Putem spune că în prima jumătate a secolului al XIX-lea, traducerile legislației austriece au un aport important în depăşirea practicilor medievale de pedepsire și audiere, precum și a justiției de clasă, și în încadrarea în gîndirea juridică modernă central-europeană. Reforma legislativă românească, la bazele căreia stau și textele juridice austriece, a facilitat în 1864 alcătuirea unui nou cod civil după modelul francez, Code Napoléon. Traducerile legislației austriece stau dovadă pentru nivelele la care s-a produs procesul de modernizare în contextul relației specifice între centrul Viena și periferie, între metropolă și provincie, avînd într-o oarecare măsură impact și asupra limbajului juridic românesc.

\section{Bibliografie}

\section{A. Izvoare}

*** Publicație cuprinzînd abaterile și pedepsele ce se vor aplica celor vinovați, Joseph Edlen von Kurzbek, Viena, 1780.

*** Pravilă de obște asupra faptelor rele și a pedepsirii lor, traducere în română de Ioan Budai-Deleanu, Joseph Edlen von Kurzbek, Viena, 1788.

*** Carte de pravilă ce cuprinde legele asupra faptelor răle și a călcălilor grele de poliție, traducere în română de Toma Moldovan și Ioan Budai-Deleanu, P. Ekhard, Cernăuți, 1807. 
*** Codicele penale despre crimini, delipte și abateri, ordinăciunile despre competința județelor penali, și regulămîntul de tipariu din 27 mai 1852 pentru Imperiul Austriei, traducere în română de Eudoxiu Hurmuzachi, Hof- und Staatsdruckerei, Viena, 1853 .

\section{B. Lucrări de referință}

Coșeriu, E. (1998). Relația dintre lingvistica contrastivă și traducere, în „Analele Științifice ale Universității «Alexandru Ioan Cuza » din Iași. Secțiunea Limbi și literaturi străine”, traducere de Casia Cujbă, Editura Universității „Alexandru Ioan Cuza” Iași, p. 5-20.

Cujbă, C. (1999). Influența germană asupra vocabularului limbii române literare contemporane, Paideia, București.

Flechtenmacher, C. \& Cuzanos, A. (1815). Scară a cuvintelor celor streine și celor făcute din firea limbii, care cuvinte au cerut neapărat trebuința a se metahirisi în alcătuirea prevililor, Mitropolia Moldovei, Iași.

Gheție, I. (1975). Baza dialectală a românei literare, Editura Academiei, București.

Jumugă, M.G. (1986). Rumänische Einflüsse in den deutschen Siedlungsmundarten und in der deutschen Umgangssprache der Bukowina, în Interferențe culturale româno-germane. Contribuții ieșene de germanistică, $I V$, ed. de Andrei Corbea și Octavian Nicolae, Editura Universității, Iași, p. 41-46.

Kremnitz, G. (1994). Gesellschaftliche Mehrsprachigkeit. Institutionelle, gesellschaftliche und individuelle Aspekte. Ein einführender Überblick, Braumüller, Viena.

Minuț, A.M. \& Lihaciu, I. (2014). Interpolarea ca strategie de traducere a Istoriei universale adecă de obște, care cuprinde în sine întîmplärile veacurilor vechi, versiune în limba română de Ioan Piuariu Molnar, în Impulsul iluminismului în traduceri românești din secolul al XVIII-lea, ed. de Eugenia Dima și Andrei Corbea-Hoișie, Editura Universității „Alexandru Ioan Cuza” Iași, p. 91-136.

Protopopescu, L. (1967). Noi contribuții la bibliografia lui Ion Budai-Deleanu. Documente inedite, Editura Academiei, București.

Zup, I. (2015a). Die Übersetzungen der Habsburgischen Strafgesetzbücher ins Rumänische, în „ANADISS. Journal of the Discourse Analysis Research Centre", nr. 19, p. 187-198.

Zup, I. (2015b). Traducerile legislației austriece în Bucovina habsburgică (1775-1918), Editura Universității „Alexandru Ioan Cuza" Iași. 